\title{
Indian womb - German baby: transnational gestational surrogacy in the film Monsoon Baby (2014)
}

Waltraud Maierhofer(D

Correspondence: Waltraudmaierhofer@uiowa.edu

German Department, PH 101, University of lowa, lowa City, IA 52242-1323, USA

\begin{abstract}
The film Monsoon Baby (2014) by Andreas Kleinert sympathetically shows the needs of the German couple seeking parenthood by gestational carrier in India. I argue that it also takes a strong stand against commercial surrogacy abroad because it points out legal issues and-more importantly-shows how surrogacy work can exploit women's bodies, emotions, mental and physical health and even lives. From a postcolonial perspective, it is also problematic because it contains neo-colonial topoi and attitudes. Surrogacy with foreign intended parents has in the meantime been banned in India, but it may just move to other countries. Monsoon Baby remains an important contribution to the public debate about reproductive rights and choices as well as global reproductive justice.

Keywords: Cultural studies, Film analysis, Germany, Gestational carrier, India, Monsoon baby, Neocolonialism, Reproductive rights, Surrogacy
\end{abstract}

\section{Transnational surrogacy and German law: A "legal no man's land"}

"Oh, if only we had a child!" - The tale of "Briar Rose" or "Sleeping Beauty" as told by the Grimms knows of the sad or desperate wish of couples for a child of their own (Zipes 1992, p. 186). In "Hans My Hedgehog," a rich farmer goes so far as to exclaim, "I want to have a child, even if it's a hedgehog" (Zipes 1992, p. 393). Today, it is not supernatural forces who fulfill such wishes but fertility clinics. Among Hollywood celebrities, it has become not so extraordinary any more to have a child using a gestational carrier, an unrelated woman who gets the embryo implanted which was created "in vitro" from ovum and semen by the intended parents (or one of them and a donor in a same-sex-relationship), and she delivers the baby. Magazines regularly publish lists of famous couples who had pregnancies by carriers (for example, Juneau 2019). In Germany, such reports and the accompanying photos of happy families used to be seen as a curiosity and glimpse into the world of the rich and famous until news of German couples seeking surrogate mothers abroad made headlines. In Germany, Austria, and Switzerland surrogacy is illegal according to the German Embryo Protection Act (Gesetz zum Schutz von Embryonen - ESchG) (see Bundesministerium der Justiz

(c) The Author(s). 2019 Open Access This article is distributed under the terms of the Creative Commons Attribution 4.0 International License (http://creativecommons.org/licenses/by/4.0/), which permits unrestricted use, distribution, and reproduction in any medium, provided you give appropriate credit to the original author(s) and the source, provide a link to the Creative Commons license, and indicate if changes were made. 
und für Verbraucherschutz 1990, $\mathbb{\$} 1) .{ }^{1}$ The result is couples seeking the "service" in countries where it is legally available. Statistics are not available but according to estimates Germany ranks number two worldwide in surrogacies abroad (Calla 2017).

The German law (Bürgerliches Gesetzbuch) defines as mother of a child the woman who has given birth to it (see Bundesministerium der Justiz und Verbraucherschutz 2019, $\$$ 1591). In March 2019, the Federal Court of Justice (Bundesgerich tshof, BGH) affirmed this law (see the report by Sehl 2019). Because of this fact until recently a child born by a gestational carrier abroad could only gain status as a legal child in Germany by forged documents or by adoption. For example, in 2010 twins born in India by a surrogate were refused a German passport and could not join their German "parents" for two years until a special visa was granted (Spiewak 2010). In 2012, reports of a symposium of the German registrars of births etc. (Standesbeamte) drew public attention to the legal complications after assisted reproduction. A registrar broke the law if $\mathrm{s} /$ he registered a child they suspected or knew as being born by surrogate as a biological child, and the symposium argued for a revision of the law in order to provide legal clarity for the families (Straßmann 2012; for a report on the symposium see Beck 2013).

This situation of a child "in a legal no man's land" (Duden and Basedow 2015/ 2016) seems to have been one of the issues which inspired the film to be examined in the following article. The TV drama (Monsoon Baby 2014) by director Andreas Kleinert (born 1962) stars very popular actors. Julia Jentsch and Robert Kuchenbuch are a childless middle-class German couple who turn to a surrogacy clinic in India in order to fulfill their dream of a child of their own. The end leaves open whether they will be able to keep the child and bring it to Germany as their own. A made-for-television feature film can address a controversial topic, introduce it to a large audience and motivate further inquiry and discussion. Monsoon Baby is an important contribution to the public debate about reproductive rights and choices given medical possibilities. Similar to other Western representations the film focuses on the needs of the commissioning couple. I argue that it also takes a strong stand against surrogacy because it points out legal issues and-more importantlyshows how surrogacy work can exploit women's bodies, emotions, mental and physical health and even lives. From a postcolonial perspective, it is also problematic because it contains neo-colonial topoi and attitudes.

Surrogacy with foreign intended parents has in the meantime been banned in India, but it is feared that it may just move to other countries such as Bangladesh. In 2018, after two years of discussion, a new bill regulating surrogacy in India came into effect. It bans all foreign and homosexual applicants and commercial components. Supporters hope that the bill will "stop 'rent a womb' exploitation of vulnerable women" (Ray 2018; for a critical summary of the bill see Ravi 2016). Opponents argue it could push surrogacy underground or into other countries with little regulation such as Cambodia, it denies women access to a legitimate source of income, and limits their reproductive rights (Bassan 2018). The main issue continues and thus the relevance of the film.

${ }^{1}$ In early 2018, a citizen initiative started a proposal to parliament with the goal of adapting the law governing surrogacy to the "reality of live"; see "Neuigkeiten zu Leihmutterschaft and Eizellspende 2018. As of November 2019 the petition has not been successful. 
Kleinert wrote the script of Monsoon Baby together with the journalist and script writer Florian Hanig (born 1968) who worked, among other places in Bangalore, India, and has excellent insights into the culture. The press release of the film contains an interview in which Hanig emphasizes not only his research of surrogacy in India and South Africa for a report he wrote for the popular magazine GEO, the responses by affected couples as well as his own observations among friends who were childless and unsuccessfully seeking medically assisted reproduction (Monsoon Baby: Drehbuchautor Florian Hanig 2014; see the reports Hanig 2011 and Hanig 2012).

The larger context of the film, as indicated above, is the discourse of infertility and medically assisted reproduction. A low birth rate in Germany (as in other countries of the global North) and changing family structures and gender roles provide the larger context of cultural and political anxieties that show up in political slogans, often linked with immigration. Some couples travel abroad to undergo treatment that is not possible in Germany for a variety of reasons. A study about reproductive tourism by Profamilia, the German association for family planning, sexual education, and counseling (Thorn 2008), found with regard to international surrogacy:

This phenomenon is increasingly being addressed, both in professional circles and in the media, even if the proportion of these couples in the total number of couples undergoing reproductive medicine is probably relatively small. It has become a controversial and vexed topic that is evaluated differently by stakeholders. The interpretations range from the exercise of reproductive autonomy to civil disobedience to an illegal and punishable act (Thorn 2008). ${ }^{2}$

The rich academic literature on commercial surrogacy, especially in India, in English but also in German includes case studies and ethnographic responses, it addresses ethical questions, examines systemic injustices, applies feminist and other theoretical perspectives and investigates practical and legal issues such as citizenship, nationality, state power, and bureaucracy. ${ }^{3}$ Popular media undoubtedly influence public perception and opinion about controversial topics. Fictional and autobiographical writing about surrogacy usually emphasizes emotional aspects and personal values. It is therefore remarkable that the film also touches on legal issues. The German public television station ARD first aired Monsoon Baby on September 14, 2014, in the same year when the nonfiction book titled Kinder machen: Neue Reproduktionstechnologien und die Ordnung der Familie (2014, Making children: New reproductive technologies and the order of the family) by journalist and cultural historian Andreas Bernard became an immediate bestseller and popular talk show topic (Bernard 2014). German public television aired the documentary film Leihmutterschaft - Gekauftes Elternglück (directed by Susana Santina and Peter Böhmer, 2015; Surrogacy: Happiness as parents for sale). ${ }^{4}$ Cultural historian Bernard is skeptical of the reproductive medical industry including surrogacy.

\footnotetext{
${ }^{2}$ All translations from German are my own, unless a published translation is quoted. This includes the film Monsoon Baby which is not available with English subtitles. It only has a few phrases and sentences in English.

${ }^{3}$ See Goeldel 1994; Schuh 2013; Diel 2014; Oelsner and Lehmkuhl 2016; Lammers 2017 to name just a few major German-language publications.

${ }^{4}$ According to the press release by the TV station, it was first broadcast on Nov. 10, 2015 (Leihmutterschaft: ZDFinfo 2015).
} 
He claims colonization and exploitation of the female body as one of the effects although he does not see new practices as endangering the titular order of the nuclear family but on the contrary affirming it. He is in line with recent anglophone research on commercial surrogacy in India which in the words of Ana Mendes and Lisa Lau has "consistently highlighted the high potential for exploitation of poorer women's labor, the systemic biopolitical imbalances and cultural misunderstandings that complicate the process" (Mendes and Lau 2019).

This article applies a postcolonial perspective to the film, using the re-orientalist framing that Mendes and Lau have developed and applied to the English novel The House of Hidden Mothers (2015) by Meera Syal, a British author with Indian background (Mendes and Lau 2019). Edward Said's Orientalism (1978) laid the foundation for Postcolonial Studies. He argued that the discourse of the orient was shaped by European values and categories and that "orientalism" affirmed European identity (Said 1978, p. 46). Recently, Lau and Mendes have outlined "re-orientalism" as a new paradigm that could provide "a new form and frame of analysis for theorizing and interpreting currently developing cultural relations between, in particular, Europe and Asia" (Lau and Mendes 2011). They have critiqued the Indian practice of international commercial gestational surrogacy (ICGS) between 2002 and 2018 as an alarming example of a gendered, neo-colonial practice because in Indian surrogacy clinics former colonizers controlled people of former colonies (see Saravanan 2018, p. 134). ${ }^{5}$ Some scholars argue that even the pattern of groupings such as "Indian women," "Third-world women," "Western women" etc. denotes neo-colonialism and not post-colonialism (Saravanan 2018, p. 134). It commonly occurs in reviews of the film. The first section will therefore investigate the "Othering" of India in the film and seek out manifestations of re-orientalism.

Western writers and filmmakers, even if they subscribe to furthering women's rights, tend to colonize women's lives in the global South, continue to construct the "Indian woman" as poor, oppressed, and in need of rescue, presenting Western ideals as liberating, as Chandra Mohanty has pointed out (Mohanty 2003; see also Bailey 2014, p. 2425). This is clearly the case in Monsoon Baby but this observation does not devalue the film overall; it continues to be is an important contribution to the discourse, with the potential of raising awareness of multiple issues.

This article examines how the film sympathetically shows both the needs of the couple who want to have a biological child, and the reasons of an Indian woman for carrying a foreign couple's child in an attempt to improve her family's future. However, techniques of othering and re-orientalism are applied to both the Indian birth mother and India overall. The representation is strongly tilted towards commercial surrogacy in India as exploitation and will likely influence the viewer in this way. ${ }^{6}$ The emotional and sensational side is clearly foregrounded, while the role of the Indian doctor and her business are downplayed, a trait the film shares with English-language fiction on the topic. I will show how the North-South tension and colonial legacy are expressed in images rather than dialogue. Monsoon Baby realistically points out complications created by the German and Indian

\footnotetext{
${ }^{5}$ The case studies in Saravanan 2018 include two with intended parents from Germany.

${ }^{6}$ Reviews of the film in major German newspapers were remarkably non-judgmental and applauded the multi-faceted and non-moralistic portrayal. See Hannemann 2014, Buß 2014
} 
citizenship laws, and leaves open the solution of the legal problems. The sad ending encourages reflection beyond the ethics and economics of international gestational surrogacy. Since illegality and exploitation do not stop couples from seeking surrogacy abroad, should the German law be adjusted to the reality? A final section will outline that such a change is in the meantime practically the case.

\section{Surrogacy Industry in India and Fictional Representation}

Mendes and Lau aptly introduce their article on surrogacy in India in (Syal's The House of Hidden Mothers (Syal 2015) as follows:

The branding and marketing of post-millennial India as a global service provider has been relentless. Indian cities have now been de-exoticized from their previous association to elephants, snake-charmers, and slums, and are now being marketed as the hub of Global North medical infrastructure and scientific advancement, at attractive Global South rates. Legalized only in 2002, international commercial gestational surrogacy (ICGS) in India, a lucrative niche market within the sector of medical and healthcare tourism, has been an industry worth US\$ 2.3 billion annually at its peak (Mendes and Lau 2019, p. 318).

The boom began in 2004 with the success of Dr. Nayna Patel's fertility clinic in Anand, Gujarat in Western India. The clinic has become the subject of several studies. ${ }^{7}$ It also featured prominently in documentary films including Zippi Brand Frank's Google Baby (2009) about the global baby-making industry (Google_Baby. Directed by Zippi Brand Frank 2009). A surrogate pregnancy in India in the early 2010s was much more affordable than in the USA or Belgium, a fact which is mentioned in the film. Defenders of legal surrogacy argue that it was for many women in India a form of reproductive labor that was well paid in comparison to other forms of labor. Sociologist Amrita Pande found that in 2006 compensation for surrogacy in the amount of $\$ 3000$ to 5000 was "equivalent to approximately five years of total family income" (Pande 2014a, p. 20). Doctors in India are highly qualified, and English is spoken, making Indian fertility clinics a convenient destination for European couples. For a feature film, India provides a colorful backdrop with endless possibilities and at the same time evokes cultural anxieties such as the German anti-immigration slogan from 2000, "Children instead of Indians".

Monsoon Baby is only one work of plentiful Western representations of commercial gestational surrogacy in India but it is the first and so far only fictional work in German. ${ }^{9}$ In addition to abundant reports, blogs, and websites, filmic and literary representations started with Hindi films for Indian consumption. The first film to have surrogacy as its topic was Doosri Dulhan (directed by Tandon, 1983; Second bride). Chori Chori Chupke Chupke (directed by Abbas and Mustan, 2001; Secretly and

\footnotetext{
${ }^{7}$ Patel's clinic is studied for example in the following publications: Lewis 2019, Chavkin and Maher 2010, DasGupta and Dasgupta 2014. There are also several videos with Patel on platforms such as Youtube, for example the TED talk "Surrogacy in India" 2016.

${ }^{8}$ The politician Jürgen Rüttger (CDU) coined "Kinder statt Inder" in 2000 to express his conviction that Germany should train its own computer specialists instead of recruiting them from countries such as India.

${ }^{9}$ There are recent German novels about surrogate mothers but they are not transnational and do not involve a gestational carrier, that is the surrogates get pregnant with their own ova. They revolve around a widow wishing for a child of her dying son (Milan 2018) and a woman earning money for her husband's operation (Fischer 2017).
} 
stealthily) became a box office hit. The Indian scholar Anandita Majumdar observes in her monograph on commercial surrogacy that both films depict surrogates as prostitutes or aberrant women who lack motherliness, are likely to give away their children, and sell their bodies as commodities (Majumdar 2017, p. 14). In the 2000s the Hindi Bollywood films Filhaal (directed by Gulzar, 2000; Momentary) and Janani (directed by Bahl, 2006) explored surrogacy pregnancies undertaken out of an altruistic motivation with emphasis on the resulting conflicts between the intended mothers and the birth mothers. The short film I am: Afia (directed by Onir, 2011) and the film Sita (directed by Arpita Kumar, 2013) are recent examples of crowd-funded independent films; Ana Mendes investigates their depiction of the birth mothers as the "contested bodies of neoliberalism" (see Mendes 2018). Two English novels by diasporic Indian-British and Indian-US American authors appeared shortly after Monsoon Baby: The House of Hidden Mothers (2015) by Meera Syal and A House for Happy Mothers (2016) by Amulya Malladi (This novel is so far the only one available in German translation; Malladi 2017). Both foreground the lives, emotions, and concerns of the intended parents, especially mothers (see Mendes and Lau 2019). ${ }^{10}$ To move into biographical and autobiographical writing, the collection Baby Makers: A Story of Indian Surrogacy (2014) by Indian journalist and writer Gita Aravamudan stands out. She has written several profound studies on gender issues in India, and for this book has collated real surrogacy stories, all emotionally charged situations. In all the stories selected in the volume the intended mothers appear as the driving force behind the surrogacy business. Motivations very similar to those of Monsoon Baby lie behind an autobiographical account from Ireland, Baby Ava: An Irish Surrogacy Story (O'Flaherty, Baby Ava 2012). Although there is no law regulating surrogacy in Ireland, the birth mother is considered the legal mother. The couple has difficulties obtaining an Irish passport for "their" child born in India and spends time in "limbo." Unlike Monsoon Baby the story concludes with the baby's legal transfer to Ireland and a happy end for the family.

\section{The Chaos of India: Postcolonial or Neocolonial?}

For a fictional representation of transnational surrogacy in India it is important how the North-South relationship and the colonial and orientalist legacy are addressed. It is telling how Monsoon Baby opens with scenes of the couple who just arrived in an Indian city, exhausted from the heat, taking pictures from the taxi, fascinated by its colors and street life which includes a cow and rows of colonialera buildings. Nina is eager to explore but the audience learns soon that they have come to India for a very particular reason. This visual introduction follows the traditional European view of India as visually appealing (Augenweide) and a timeless place of longing ("zeitlosen Sehnsuchtsort"), as Angela Müller writes in her recent study of the visual imaginary of India in German print media (Müller 2019, p. 28). A few scenes later, the city is identified as Kolkata. In the film the former name Calkutta (Kalkutta) is used, although officially the Bengali name replaced the English in 2001, reflecting anticolonial attitudes. The location was likely motivated by the role of the large wetlands East of Kolkata later in the plot. For a

${ }^{10}$ So far only Malladi's is available in German translation; see Malladi 2017. 
postcolonial reading it is not insignificant that the capital of the former British colony British India was chosen as location, not the large Rotunda Medical Center in Mumbai or the well-known smaller practice by Dr. Patel in Gujarat. Kolkata is the principal commercial, cultural, and educational center of East India and the "next global city". ${ }^{11}$ However, due to the legacy of Mother Teresa, often called the "Saint of the Poor" or "Saint of the Slums". ${ }^{12}$ Kolkata is still disproportionately associated with poverty in India. There are significant geographical differences in Indian women's participation in the workforce and consequently in how they are treated: it is higher as one goes north to south and east to west on the subcontinent.

In Monsoon Baby, the combination of poverty and surrogacy work will endanger a live and destroy a family. The images and scenes chosen for the film (camera Andreas Höfer) are not zooming in on the elite and middle class, on audacious reforms and economic growth, on IT industry and shopping malls, but they depict an "other" world that is at best fascinating and exotic to the European visitor, at worst frightening and dangerous. It is a traditional view of India as "land of beggars and gurus, holy cows and palaces" as it is still prevalent in Germany today (Freyer et al. 2011, p. 189). Life in India (at least for the poor) is defined in negative terms whereby German/European standards of living represent the subjective position from which India and its lowincome women are objectified. Representation of the other as fascination can quickly lead to the objectification and even the commodification of the other. The only welleducated middle-class female Indian character in the film, the doctor, fulfills a questionable role in this objectification which will be examined in the respective section.

Even the title plays into the depiction of the exotic. The title "Monsoon Baby" immediately evokes images of India. Rain in India is restricted to three to four months in summer and most important for agriculture and economy. The monsoon ends the long hot and dry season and marks the return of life, much like spring in other regions. The start of crop-planting is dependent on the monsoon, and it has often been called the "life-blood" of India's US\$2.5 trillion farm-dependent economy (most recently Jadhav 2019). "Monsoon" more than any sight evokes India, ${ }^{13}$ is reason for celebrations, and is spiritually significant. Remarkably, the meaning of "Monsoon Baby" is not explained in the film and remains mysterious but there are several important allusions. In ancient Vedic culture, the cult of the rain baby Kamara, son of the Gods Shiva and Paravati, is central, and it is still preserved in certain regions, such as Nepal (Vajracharya 2013). As part of the harvest festivals at the end of the monsoon season, the sky is ritually "impregnated." It is believed the clouds are pregnant with the monsoon rains for a period of about nine months before giving birth to them. The festival for the rain baby marks the first rain of the season and also celebrates the birthday of mythological Kamara. In colorful images in Monsoon Baby, the surrogate mother is seen rejoicing in the rain, one of only two scenes that show her as happy. ${ }^{14}$ She also attends a street festival with her family. It is possibly ironic that Nina

\footnotetext{
${ }^{11}$ This phrase is the title of the respective chapter on Kolkata in Kaplan 2011, p. 155-178.

${ }^{12}$ The latter is the title of the graphic novel by Helfand 2013.

13"Monsoon" is for example also the title of a popular geopolitical study on the Indian Ocean area (known as "Monsoon Asia") and American foreign policy; see Kaplan 2011, p. 155-178. A new travelogue on the Indian Ocean countries is titled Monsoon Postcards (Mould 2019).

${ }^{14}$ A still image of this scene (see Drama mit Julia Jentsch 2017), part of the press release, was chosen for several film reviews. Because these images are available online, they are not included with this study. See on the same site for example the situations discussed below of the couple on the boat and with the baby.
} 
brings her a raincoat as a present from Germany. If the child of the sky goddess is not properly honored he can bring great harm to the harvest and thus to people. One might speculate about foreshadowing with the title. The birth mother comes to harm because she did not honor the Indian tradition of patriarchy and the authority of her husband in her decision to earn extra money as a surrogate. Otherwise, the rain is not a factor in the plot such as in finding the birth mother. ${ }^{15}$

Besides the monsoon and poverty, the tropes of India most invoked in the film are chaos and spices. Mark finds the food too spicy. In an early scene when the couple fantasizes about their future child, Nina anticipates her baby smelling of Indian spices. She states at one point to her father that she has an affinity to India and its "chaos". ${ }^{16}$ During her time in India Nina adjusts her appearance to include a sari-like shawl. She learns to negotiate, for example the amount she pays for a bicycle. Still, she is used to orderly procedures, and when Shanti disappears, she calls on the police to find Shanti's husband. They even beat him up in the effort to get the information about her whereabouts. Nina disapproves but has to accept the Indian ways.

Parts of the film feel like a travel feature. For example, Nina watches people at a temple and taking a ritual bath in a river, and she seems to absorb the spirituality. Once, Nina gets lost at night in a deserted neighborhood that looks more and more threatening for a woman alone. She is "rescued" by her husband back in Germany on the phone who guides her back to her hotel using the GPS of her phone. There are many details that show India as backward: When searching for the birth mother Shanti, the viewer sees them take a crowded battered bus and a simple boat. The clinic/surrogacy home is in a deteriorating colonial building with old computers instead of state-of-the-art equipment. The couple pays the clinic with a large bundle of money instead of an abstract form of payment by card or bank transfer.

The scenes that condense the neo-colonial issue at hand are the birth scenes. A birth scene about two thirds into the film highlights the contrast of a lightskinned baby being taken from a dark-skinned woman. Notably, one of the working titles of the film was "Weißes Baby, brauner Bauch" ("White baby, brown belly") ("Monsoon Baby," Crew United n.d.). Nina assists the doctor, giving commands to the delivering woman in English and pressing her hand in support. The baby's white skin is only visible when Nina holds it before bringing it to the happy French-speaking white couple who have been watching. I will return to this scene below.

\section{“I Want My Own Child": The Intended Parents}

From the above short survey of fictional representation, it is obvious, that stories published primarily for a European or US-American audience tend to foreground the woman from one of these countries seeking surrogacy in India, her needs and

\footnotetext{
${ }^{15}$ There is a story with the same title, Monsoon Baby, where the rain presents danger. It is by Canadian author Jonathan Derksen (2018), originally an MFA thesis at the University of British Columbia, 2013. A Canadian expat couple expects their first bably during the monsoon in the Himalayas.

${ }^{16}$ Her description of India and Kalkota as "chaos" is certainly not original; a quick search encounters it as title word in travelogues as well as historical and political studies, such as Rosenthaler 2004, Miglani 2013, Wilson 2016.
} 
emotions, over that of the birth mother and the extent of her agency. Monsoon Baby is no exception. Although it sets out to affirm the birth mother's agency, it is then rescinded.

The intended parents are represented not a glamorous couple or eccentrics but an average middle-class couple. It is not just the gated luxury hotel that the German couple can afford in India but also a gestational carrier. Mark Volkert is a carpenter, his long-time girlfriend Nina a nurse. Although they find marriage "petit-bourgeois" (kleinbürgerlich) they wish for a traditional family with a biological child. Nina appears as the driving force because she is desperate to become a mother. Her wishes are foregrounded when the Indian doctor questions them about their desire for a child. Nina seems genuinely sad and upset when she recalls how they tried for eight years. She mentions three miscarriages and the fact that she underwent hormone treatments and artificial insemination. Now she is "nearly forty." She does not want to adopt, saying in another scene to her friend, "I don't want someone else's child. I want my own child" ("Ich will kein fremdes Kind. Ich will mein Kind.") She therefore turned to surrogacy abroad, determined to take one "last chance."

They chose India with its much lower cost for surrogacy over California because after many fertility treatments they are "practically broke." Why a couple would want a child in such a situation is a different question and shines a skeptical light on their capacity for rational planning and evaluation of all factors. This is augmented a little later in the film when the audience learns of difficulties with the family business that Mark and his brother run. A wish for a child of her own appears very selfish. On the other hand, Nina is clearly influenced by societal expectations of women. These are personified in her mother-in-law. She is not subtle in expressing her expectations of a grandchild and exerts some pressure on Nina. The viewer learns surprisingly little of Mark's wish for a child. He seems to go along with Nina's desires.

It later turns out that Nina has a wealthy father who would have financed birth by a gestational carrier in the US. It is obvious she wanted to prove to herself that she could manage on her own although she appears to be the only child and heir. Another sign of poor planning is the fact that the couple only finds out in the clinic that in India a surrogacy was only granted to married couples. ${ }^{17}$ However, this plot element is important for drawing the viewer into the film and for getting a better sense of their relationship. It is very loving but stressed by Nina's unfulfilled desire for a child. The complication gives the plot an occasion for a romantic marriage proposal and happy scenes of their wedding with colorful Indian dress and cheerful music before the film grows increasingly serious and sad. Here again, India is shown as "other" world where the wedding-rejected at home-becomes exotic.

The couple gets to choose the carrier from a group of three women presented at the clinic. This plot element appears unrealistic but is important in the film because it emphasizes choice. Both the birth mother and the intended mother make a deliberate choice. According to reports of the exemplary clinic by Dr. Patel including the Irish autobiographical account, it is the clinic that selected the birth mothers (O'Flaherty 2012, chap. 7). Nina's choice is based on her feelings and the relationship she

\footnotetext{
${ }^{17}$ O'Flaherty for example describes an extensive consultation session including phone conversations with the clinic before the intended parents travel to India, and she also mentions a helpful forum on the clinic's website; see O’Flaherty 2012, chap. 7.
} 
imagines with the prospects, not on a weighing of appropriate prerequisites and screening processes. Nina is first overwhelmed by the task and defers to Mark who asks the three women why they want to be carriers. The doctor translates their hesitant answers in their language, summarizing "They are glad that they can help you have children. They like to be pregnant." When Mark pauses Shanti speaks up, while the camera focuses on her expressive face dominated by kayaled eyes and framed by long black waves of hair. This is the only time in the film that Shanti talks to the couple in a lively and eager manner. The doctor translates that she wants to better the life of her son and that is why she wants to "help" them. What is not explained is the educational system and its colonial legacy: What Shanti means is most likely sending him to a private school which are better than the public ones but charge high tuition, a reality Nina and Mark would not be familiar with.

The camouflaging of surrogacy work as women helping each other will be discussed more in the section on the clinic. Nina in an immediate intuitive decision selects the young woman who appears most emotional about it, Shanti. She also seems to be the most likable and gentle, which evokes a possible personal relationship. ${ }^{18}$ The viewer immediately feels sympathy for her, but compared to criteria for gestational carriers as Bernard has found in his investigations, she would be an unlikely candidate under pragmatic considerations. ${ }^{19}$ The couple will later realize that Shanti has secrets which lead to complications, secrets that an experienced clinic would find out early.

There are several instances where the film shows cultural differences and Nina's lack of awareness. Contrary to her expectations, Shanti does not want to relate to the commissioning parents and she needs privacy. For example, when Nina learns of the successful implantation, she is euphoric and embraces Shanti who stands motionless and does not welcome such intimacy. Nina and Mark do not understand the norms and preferences of lower-class Indian life. This results in imposition, patronizing, and, ultimately, othering. The doctor does translate what little Shanti says, but she does not negotiate cultural differences.

Despite these shortcomings, the portrayal of Nina is so that it creates empathy for her. The viewer is not supposed to condemn her for choosing an illegal path or exploiting another woman. She is shown as a person who wants to do good and help others. The audience learns her profession rather late after she quits her job in Germany to be near the pregnant Shanti. It was a highly emotional decision that excluded her husband. Because Nina is a nurse, she wants to "help" in the clinic, and is accepted. For her time money is never mentioned. She is deeply affected by what she sees at the side of the birth mothers, feels sincere empathy, and is torn about her own role.

It is not convenience or vanity why she is commissioning another woman to carry her child. On the contrary, she is shown as feeling guilty about not sharing

\footnotetext{
${ }^{18}$ Tillotama S Shome is an Indian actress who studied in New York and is currently based in Mumbai. She has played roles in English, Hindi, Bengali, Punjabi, and Nepali. See her website, "Tillotama Shome".

${ }^{19}$ Bernard describes in his section on a surrogacy clinic in the Ukraine its selection criteria for professional gestational carriers: not married, experience with birth, reliability, maturity, and minimal risk of an emotional bond or other complications (Bernard 2014, p. 349-365).
} 
the negative effects of pregnancy, about not suffering from morning sickness, not having to give up coffee and alcohol. She is also frustrated because she wants to be a good mother, beginning with the pregnancy. This is why during the time back in Germany she hangs up ultrasound images and records a nursery song to send to Shanti and play to her unborn.

The viewer may even feel sorry for Nina when she expresses disgust with her own body. She refuses to wear the "pregnancy bellies" which her husband bought for her in order to better pretend that she herself is pregnant which is apparently what they had planned. When she finally confesses to a friend that she is using an Indian woman as the carrier of her child, she also has to face questions about its political and moral implications. Her friend Nora reminds her she is committing an illegal act. She also confronts Nina about the economic difference, saying, "You are taking advantage of a situation of need!" This point is the core issue of the film. Nina argues that it was the Indian woman's free choice and the amount earned is a small fortune for her and will help her in improving her life, a point often heard in the debates about surrogacy and addressed more below.

The viewer gets a closer, uncomfortable look at such a situation of need and the consequences by the portrayal and (dramatized) story of the birth mother in India in the remainder of the film. Shanti remains subaltern to Nina as the female lead of the film, and only minimal background to her family and motivations is provided. She never gets a last name, and her husband has no name at all. Her only other utterings, namely when she talks with other women in the clinic and later her crying in pain, are not translated or subtitled.

\section{The Colonialized Body: The Birth Mother(s)}

When the three potential birth mothers first walk across the courtyard of the clinic, the contrast to the light-haired white European couple is striking. Mark and Nina are wearing jeans and $\mathrm{T}$-shirt/blouse and are obviously deranged from the heat. The Indian women look fresh, walk briskly, are clothed in long saris in bold colors and wear bindi marks on their foreheads, clearly marking them with their cultural background. ${ }^{20}$ Their black hair is nicely combed, and they maintain good composure. They return the offered handshake with the common Indian greeting of pressing the palms together in a prayer position accompanied with a slight bow. They are thus orientalized while he female Indian doctor is not. The doctor has a caring, motherly demeanor and introduces herself only by first name, Kamalika (played by Swaroopa Gosh, an award-winning Bollywood actress), suggesting she is supposed to be a type rather than an individual, even a friend. She is initially mostly seen in her white lab coat over her modest black and white dress and pants, marking her as educated and "Western." One of her first sentences is that she studied in Heidelberg, hence her German proficiency, and she also speaks English, while the birth mothers don't-at least are not heard doing so. Language and appearance mark the power and class differentiation between them.

The selection scene described above gives the audience a glimpse into Shanti's hopes and dreams for the future. With stating them for her son instead of herself, she conforms with gendered expectations of mothers as self-sacrificing. Her

${ }^{20}$ This image is also on the TV stations film information, Drama mit Julia Jentsch 2017. 
energetic short statement reveals that she is daring and ambitious despite her low class standing and lack of education. Surrogacy work opens a previously unthinkable opportunity for her. She knows intuitively to tie her desire into the language of "helping." Scholarship has confirmed the "rhetoric of altruism" as pervading the discourse of surrogacy in India (see for example Pande 2014b, p. 92). In this scene it is appealing to the intended parents because they don't want to appear as exploiting a need with their money. As a result, Mark is in a position to accept Shanti's help (which is literally his response, "Wir nehmen Ihre Hilfe an") instead of selecting a carrier based on the couple's wishes, appearing egotistical. He becomes the receiver of a gift as opposed to the neo-colonial employer and exploiter. Shanti, however, risks everything for it (her marriage and family life) and is aware of the pretense of an exchange among equals. In later scenes she is seen as open and unreserved only among a group of birth mothers.

Shanti using the language of help can be tied to Hindu beliefs in fertility gods and giving the divine gift of life to a fellow human being. Amrita Pande in her book Wombs in Labor (Pande 2014a) examines surrogacy in India. She found similar statements by gestational carriers who further emphasized that it was God's choice not their own. However, she also found that in real cases it was not so much the birth mothers who invoked altruism, stating, “The missionary zeal and the idiom of 'divine gift giving' ... are aggressively evoked by three different sets of actors-the doctor, the brokers, and the intended mothers" (Pande 2014a, p. 93). As seen above, Nina has a particular need to offer "help" to the clinic and the birth mothers in return. The doctor also chimes in on this idiom.

Shanti's fate personifies everything that can go wrong with international surrogacy, even if it is exaggerated for dramatic effect. It turns out that Shanti had faked her husband's approval-a plot device that an experienced clinic would know to avoid. ${ }^{21} \mathrm{Her}$ life is destroyed when he finds out and casts her out of their hut in the slums. Of the husband we see and know very little. He works as a washer on the streets. He is unable to step beyond his gendered traditional role and banishes her when he finds outwhich the doctor foretells before it happens. The reasons are not discussed which is another example of othering. Shanti overstepped her bounds, and he possibly felt emasculated, humiliated for not being enough, losing his face and status as husband. The money earned apparently means nothing to him. The scene with the police beating him up shows that he may have power over his wife but he himself is at the bottom of the social hierarchy.

With Shanti's banishment by her husband and the life-threatening birth the film addresses the same issues that Mendes and Lau found for the English surrogacy novel, that is the "many risks incurred by the surrogates (including social), the unequal power differentials driving the demand and supply of this exploitative market, and the skewing of the entire surrogacy process in favour of the wishes of the intended or commissioning parents" (Mendes and Lau 2019, p. 330). Hanig, the screenwriter, explained in a

\footnotetext{
${ }^{21}$ In Patel's clinic as described by O'Flaherty 2012, this risk was avoided by having the husband and children present when the potential birth mother first met the commissioning couple. Bernard found that the Ukrainian clinic only hired single women in order to avoid a potential conflict with the German law. The birth mother's name was not entered into the birth certificate but a husband would be the legal father of the child if she were discovered (Bernard 2014, p. 365).
} 
statement in the press release that the plot was not based on a real case but a dramatic scenario: "In all cases I know, the birth took place without complications. But of course, I also asked myself: What if the surrogate pregnancy and birth did not go according to plan? In India, many things are not going as planned" ("Monsoon Baby: Drehbuchautor" 2014). The doctor, Mark, and Nina set out to find Shanti at her relatives in the wetlands ("the swamps"). They find her in an extremely bad condition, suffering from "a bad infection," tended to by an old woman. They deliver the baby by $\mathrm{C}$-section with minimal disinfection and no anesthetics. The viewer is spared the details, instead we watch Mark leaving the room and throwing up outside which conveys its horrific character. Again, the neo-colonial implications are marked visually. The film cuts from dark-skinned hands rubbing disinfectant over a brown belly with stretch marks to Nina in the door of the hut with a white baby in her arms, sharing only the tiniest of smiles with her husband about their child. The whole scene is subdued and silent, expressing Nina's feelings of guilt for the situation. The clinic and Shanti have fulfilled the contract but at what price? No dialogue answers the viewer's question, not even when a simple boat carries Shanti, lying motionless, the older woman, and child away. Will Shanti survive, and to what kind of life? Or has she already died? Was her little son banished by his father as well? Is the doctor doing nothing to treat Shanti? Her role as "rescuer" is at least dubious.

The depiction of surrogacy as exploitive of the birth mothers is not unique to the Western eye. It can be seen as continuing patterns established in the Bollywood films mentioned above, Chori Chori Chupke Chupke and Doosri Dulhan. Some Indian feminists regard the generalization, namely that only poor women and women in financial crisis undertake work as birth mothers, as not only untrue but harmful, pointing out that it thus takes away "the choice and agency of the act" (Shriva 2017).

The earlier birth scene mentioned above needs to be critiqued here as well. A young Indian mother whose white newborn is given to a European couple immediately after birth, is shown crying. ${ }^{22}$ It is Nina's interpretation that the woman is suffering because her baby has been taken. Nina is stroking her head in a helpless effort to provide comfort. Thus, the film insists on the bonding between birth mother and unborn. It is one of the first concerns that Mark has in the interview with the doctor who affirms the bond. However, an Indian feminist writer and advocate for legal surrogacy maintains that the bond is often overrated, "This feeling of discomfort or exploitation further mischaracterises surrogate mothers, who make a conscious choice and know that they are bearing the child for someone else and they are within a contract" (Shriva). Ukrainian birth mothers also described that it was important for them to see the child but that they had no issue giving it away, especially when it looked different (Bernard 2014, p. 362).

In order to keep bodily harm to the carriers to a minimum, they need to have the choice of a medically managed delivery. In the clinic that Bernard studied in the Ukraine the babies are routinely delivered by $\mathrm{C}$-section. In the filmic depiction, the

\footnotetext{
${ }^{22}$ In the interview, Hanig describes a similar scene he had witnessed in India and found "deeply disturbing" ("Monsoon Baby: Drehbuchautor Florian Hanig").
} 
women appear to undergo active birth with minimal if any pain relief, and their pain is then interpreted as being due to the separation from the child.

\section{The Doctor and the Clinic}

The doctor and her clinic are part of a complex enterprise involving brokers, hotels, advertising and web presence, etc. The film reduces it to short communications between her and the intended parents, very little with the birth mothers, and the procedures she performs on both. Of the personnel, only one other doctor is introduced but he remains in the background. As already stated, for the sake of the dramatic plot her selection criteria for the birth mothers and rules for the surrogacy home are dubious. There is little information on the consequences of a breach of contract besides the fact that the doctor claims the baby and literally goes out of her way to obtain it. She also mentions that Shanti's husband can banish his wife and keep the payment already received. She does not secure an alternative such as Dr. Patel who is known for assisting the birth mothers set up their own bank accounts (Pande 2014a, p. 94).

In a manner that is oversimplifying the issues of biopolitics involved, in the first interview with the intended parents the doctor describes surrogacy as simple outsourcing of labor and gain for both sides. This is similar to other representations of gestational surrogacy such as the documentary Google_Baby where Dr. Nayna Patel uses the expression "win-win" (Similarly Syal 2015, p. 98). The fact that the conversation with the new clients is taking place in a simple restaurant rather than her office, supports the impression of a personal relationship. The doctor alleviates moral concerns with the argument that the birth mothers know the risks and the money exchanged means "a chance for a better life." She even claims the birth mothers' stay in the surrogacy home (from the fourth month of pregnancy on) mean "holidays" for them, again suggesting something good she does for other women instead of fair payment for their labor. Remarkably, she does not mention her own earnings. She thus comes across as the selfless intermediary between women helping each other. Nina and Mark are happy that the amount they pay is a small fortune for Shanti and will better her life, so they don't feel like exploiters and can instead mask their own shame and desires. This is the extent of the discussion of the ethics of international surrogacy in the film. The rest of the discourse of the exploitative nature of the exchange is limited to a question that is never answered, "Will she survive?" Instead, we see bloody linens, an empty stare, a motionless woman floating away on a boat.

There is clearly a power differential that characterizes the interactions between Indian women from different social classes. The film shows nothing of the doctor's life and circumstances who would be upper or upper-middle class. The birth-mother, however, is clearly associated not just with working class but with gendered subordination, violence, slum-dwelling, backwards rural areas, and non-existing health care. The German couple and the doctor take on a neo-colonial role when they venture out into the wetlands to "save" the baby.

In sum, the film focusses on the emotional, particularly the intended mother's desires and anguish and the creation of bonds. The role of the doctor is problematic and not addressed. The birth mother is typecast as poor, willing, and compliant, even desperate to the extent that she cheats to get the contract and bears the consequences. These features constitute forms of re-orientalism, even if the audience is aware that the plot has 
been dramatized in order to provide an entertaining story. In the year 2014, European couples commissioning a gestational carrier in India were well aware they were part of bio-colonialism, but large parts of the audience may not have been.

\section{Legal complications: The end}

The film does not end with the couple holding a healthy baby. In the German consulate, they are confronted with the final hurdle. Even if the birth mother signed over parenthood, according to German law, the baby of a married surrogate mother is the child of her and her husband, no matter who the biological parents are. Indian law rules that the hereditary father determines the nationality of the child ("Monsoon Baby: Hintergrund-Info" 2014). The official sees through the pretense that Nina gave birth in India, accuses the couple of an illegal surrogacy, and refuses a "stamp" which is required for the exit papers and German passport for the child. As a consequence, the baby is stateless, and the parents may not leave India with her. The official accuses Nina of not even knowing the name of the woman, a metaphor for the power differential. It hits Nina hard because again she feels guilty of exploitation. She tried to relate to Shanti and caused her ruin if not death. The couple resolves that Nina stays in Kolkata while her husband leaves and takes on the legal battle to get them "home." The official's suggestion, namely to live in India, is not an option she wants to consider. The end leaves open how long it will take to have the child acknowledged as their own. In the case with a South African surrogate that Hanig reported in his 2011 article it took several weeks. The winning argument was that the child had a right to legitimacy (Abstammung) (Hanig 2011). ${ }^{23}$ The film closes with Nina with the crying baby in her arms looking out the window in her hotel room. The scene outside seems chaotic to the Western eye, no longer photo-worthy and full of adventure, but indicative of an uncertain future and the situation of the woman the German couple used to fulfill their own desires while shattering hers.

According to Konrad Duden, legal expert at the Max Planck Institute for Foreign and International Civil Law and author of a monograph on surrogacy in international law, German legal practice has recently changed in that it no longer insists on the prohibition of surrogacy (Duden 2015). Surrogacy abroad is no longer treated as a violation of basic principles of the German law (Duden and Basedow 2015/2016, p. 3). ${ }^{24}$ Duden argues: "The right of children to integration into a family with the social parents outweighs the state's interest in effective enforcement of the surrogacy ban by preventing the social parents from becoming parents. The state must recognize the normativity of the factual, namely the existence of the social family" (Duden and Basedow 2015/2016, p. 5). While legal changes can eliminate the hardships created by a child born in "legal no-man's land," the outsourcing of pregnancy to a low-income country (or low-income individuals within a highincome country) remains highly controversial.

\footnotetext{
${ }^{23}$ Bernard 2014, p. 365 lists other cases with similar results including in India in 2008.

${ }^{24}$ Duden and Basedow 2015/2016 is a short report and preview of the monograph by Duden.
} 


\section{Conclusion}

Monsoon Baby conforms to the representation of transnational surrogacy in Western media which foregrounds the desires and needs of the commissioning parents. However, the plot with the demise of the birth mother conveys strong criticism and an argument in support of its status as illegal in Germany although the moral implications for low-income contexts are not extensively discussed. The conversation about surrogacy is an important one. Despite its neo-colonial elements, Monsoon Baby with its touching story and excellent actors is well-positioned to heighten awareness of very complex questions.

There is much research and activism that undertakes to rethink contract pregnancy in low-income contexts, steps needed to ensure birth mothers' economic, emotional, and physical well-being and other rights. Therefore, my last remarks go beyond these. Early in the film, Nina reflects, "Maybe one can be happy even if you don't get everything you want." Why is there so much obsession to reproduce? Who benefits when women think they can only be happy with a biological child? How have women like Nina learned to hate their bodies and find their relationships incomplete when there is no child of their own? Portrayals of a childless woman as unhappy and self-loathing reinforce the prevalent idea of women as emotional, illogical and jealous beings, which is untrue and a harmful stereotype.

It is not only underprivileged women that are exploited in parenthood by gestational carrier. "Genetic mothering is the new language of female oppression" (Chatterjee 2018). I wish this was my original claim but I am citing a review of the study Interrogating Motherhood (2017) by the Indian feminist Jasodhara Bagchi. In the global North, Kinderwunsch has become a project like others in the planning of one's life and career, especially for women. There is increasing pressure to undergo "treatment" when the plan does not progress. The fact that with the help of medical assistance any woman and couple can have a biological child has made it nearly inacceptable socially to remain childless, be it because of biological infertility or for other reasons. It is laudable that the discourse of medically assisted reproduction shifted from dystopias a la Aldous Huxley and fears of endangering humanity to an affordable service that promotes individual happiness by overcoming life crises caused by infertility, as Andreas Bernard outlines in Kinder machen (Bernard 2014, p. 436-446). The question remains, how can we justify this obsession with individual happiness when daily headlines warn that the earth may soon become inhabitable for humans? As I write this, eighteen months before the calculated tipping point in climate change (see for example, Green 2019), the most pressing issue is not that there are too few human inhabitants on this planet.

Abbreviations

ICGS: International Commercial Gestational surrogacy; IT: Information Technology; TV: Television; US\$: United States dollar

Acknowledgements

I would like to thank the University of lowa for granting me a professional development assignment during the spring of 2019-which made the completion of this essay possible.

Authors' contributions

I, Waltraud Maierhofer, am the sole author of the manuscript. The author read and approved the final manuscript. 
Funding

The writing and preparation of the manuscript has not received institutional funding.

\section{Availability of data and materials}

The data and materials on which the manuscript is based are the scholarship that has been cited in it.

\section{Competing interests}

As the author of the manuscript I, Waltraud Maierhofer, have no competing interests related to it.

Received: 6 September 2019 Accepted: 6 November 2019

Published online: 23 December 2019

\section{References}

Bailey, Alison. 2014. Reconceiving surrogacy: Toward a reproductive justice account of Indian surrogacy. In Globalization and transnational surrogacy in India: Outsourcing life, ed. Sayantani DasGupta and Shamita Das Dasgupta, 23-44. Lanham: Lexington Books.

Bassan, Sharon. 2018. Different but same: A call for a joint pro-active regulation of cross-border egg and surrogacy markets. Health Matrix: The Journal of Law-Medicine 28: 323-374 https:/www.ncbi.nlm.nih.gov/pmc/articles/PMC6329471/. Last accessed 27 Nov 2019

Beck, Andreas. 2013. Fachtagung des BDS 2012. Verband der Standesbeamtinnen und Standesbeamten MecklenburgVorpommern, March 11. https://standesbeamte-mv.de/index.php/69-fachtagung-bds. Last accessed 27 Nov 2019.

Bernard, Andreas. 2014. Kinder machen: Neue Reproduktionstechnologien und die Ordnung der Familie — Samenspender, Leihmütter, künstliche Befruchtung. Frankfurt: Fischer.

Bundesministerium der Justiz und für Verbraucherschutz. 1990. Gesetz zum Schutz von Embryonen (Embryonenschutzgesetz ESchG), zuletzt geändert 2011. Berlin: Bundesministerium der Justiz und für Verbraucherschutz https://www.gesetze-iminternet.de/eschg/BJNR027460990.html. Last accessed 27 Nov 2019.

Bundesministerium der Justiz und Verbraucherschutz. 2002. Bürgerliches Gesetzbuch (BGB) in der Fassung der Bekanntmachung vom 2. Jan. 2002 [...], das zuletzt durch Artikel 24 des Gesetzes vom 20. November 2019 [...] geändert worden ist. https://www.gesetze-im-internet.de/bgb/index.html. Last accessed 27 Nov 2019.

Buß, Christian. 2014. ARD-Film über Leihmutterschaft: "Andere Frauen kotzen jetzt". Spiegel Online, September 16. https://www. spiegel.de/kultur/tv/monsoon-baby-in-der-ard-julia-jentsch-in-leihmutter-film-a-990717.html. Last accessed 27 Nov 2019.

Calla, Cécile. 2017. Leihmutterschaft: Kinderkriegenlassen ist okay. Zeit online, Feb. 20. https:/www.zeit.de/kultur/2017-02/ leihmutterschaft-tabu-koerper-schwangerschaft-reproduktionsmedizin/. .

Chatterjee, Priyanka. 2018. Are Mothers Machines? A Review of Interrogating Motherhood. Feminism in India, May 15. https:// feminisminindia.com/2018/05/15/interrogating-motherhood-jasodhara-bagchi/. Last accessed 27 Nov 2019.

Chavkin, Wendy, and JaneMaree Maher, eds. 2010. The globalization of motherhood: The deconstructions and reconstructions of biology and care. London: Routledge.

DasGupta, Sayantani, and Shamita Das Dasgupta, eds. 2014. Globalization and transnational surrogacy in India: Outsourcing life. Lanham: Lexington Books.

Derksen, Jonathan. 2018. Monsoon Baby. N. p.: Art of Adventure Publications.

Diel, Alexander. 2014. Leihmutterschaft und Reproduktionstourismus. Wolfgang Metzner: Frankfurt a. M.

Drama mit Julia Jentsch: Monsoon Baby. 2017. Bayerischer Rundfunk, Aug. 14. https://www.br.de/br-fernsehen/inhalt/film-undserie/monsoon-baby-julia-jentsch-robert-kuchenbuch-film100.html. Last accessed 27 Nov 2019.

Duden, Konrad. 2015. Leihmutterschaft im internationalen Privat- und Verfahrensrecht: Abstammung und ordre public im Spiegel des Verfassungs-, Völker- und Europarechts. Tübingen: Mohr Siebeck.

Duden, Konrad, and Jürgen Basedow. 2015/2016. Internationale Leihmutterschaft: Das Kind im juristischen Niemandsland / International surrogate motherhood: The child in a legal no man's land. Jahrbuch Max-Planck-Institut für ausländisches und internationales Privatrecht, vol. 2. https://www.mpg.de/9834841/JB_2016.pdf. Last accessed 27 Nov 2019.

Fischer, Marie Louise. 2017. Die Leihmutter. Kopenhagen: Saga Egmont.

Freyer, Walter, Nicole Gehre, and Marco Richter. 2011. Das Image Indiens in Deutschland. In Indien-Tourismus: Märkte StrukturenTendenzen, ed. Tatjana Thimm and Walter Freyer, 189-200. Munich: Oldenbourg Verlag.

Goeldel, Alexandra. 1994. Leihmutterschaft: Eine rechtsvergleichende Studie. Frankfurt: Peter Lang.

Google_Baby. 2009. Directed by Zippi Brand Brank. Perf. Naina Patel, Doron Mamet-Meged, Gad Levy as themselves. Documentary film. Brandcom Productions.

Green, Matthew. 2019. Think the heatwave was bad? Climate already hitting key tipping points. Reuters, July 28. https://www. reuters.com/article/us-climate-change-heatwaves/think-the-heatwave-was-bad-climate-already-hitting-key-tipping-pointsidUSKCN1UN065. Last accessed 27 Nov 2019.

Hanig, Florian. 2011. Der gekaufte Bauch. GEO (Vienna) 12: 157.

Hanig, Florian. 2012. Leihmütter: Der gekaufte Bauch. Vienna: Geo.

Hannemann, Matthias. 2014. Monsoon Baby im Ersten: Die Lüge von der eigenen Empfängnis. Frankfurter Allgemeine Zeitung, Sep 19. https://www.faz.net/aktuell/feuilleton/medien/monsoon-baby-luege-von-der-eigenen-empfaengnis-13157033. html. Last accessed 27 Nov 2019.

Helfand, Lewis. 2013. Mother Teresa: Saint of the slums. Hanover: Steerforth Press.

Jadhav, Rajendra. 2019. Summer crop sowing lags in India on slow monsoon progress. Reuters, June 17. https://www.reuters. $\mathrm{com} /$ article/us-india-monsoon-sowing/summer-crop-sowing-lags-in-india-on-slow-monsoon-progress-idUSKCN1TI13I. Last accessed 27 Nov 2019.

Juneau, Jen. 2019. 34 Famous families who've welcomed children through surrogacy. People, May 10. https://people.com/ parents/celebrities-who-have-used-surrogates/?slide=6750483\#6750483. Last accessed 27 Nov 2019.

Kaplan, Robert D. 2011. Monsoon: The Indian ocean and the future of American power. New York: Random House.

Lammers, Roman. 2017. Leihmutterschaft in Deutschland: Rechtfertigen die Menschenwürde und das Kindeswohl ein striktes Verbot? Frankfurt am Main: Peter Lang. 
Lau, Lisa, and Ana Cristina Mendes. 2011. Re-Orientalism: A new manifestation of orientalism. In Re-Orientalism and South Asian identity Politics: The oriental other within, ed. Lisa Lau and Ana Cristina Mendes, 3-16. London: Routledge. Leihmutterschaft - Gekauftes Elternglück. 2015. Directed by Susana Santina and Peter Böhmer. TV film. First airing ZDF, 15 Nov. 2015. Leihmutterschaft: ZDFinfo mit neuer Doku über das "gekaufte Elternglück". 2015. (Press release.) Presseportal, Nov. 10, https:// www.presseportal.de/pm/105413/3171294. Last accessed 27 Nov 2019.

Lewis, Sophie Anne. 2019. Full surrogacy now: Feminism against family. Brooklyn: Verso.

Majumdar, Anandita. 2017. Transnational commercial surrogacy and the (un)making of kin in India. New Delhi: Oxford University Press. Malladi, Amulya. 2017. Das Haus der glücklichen Mütter. Amazon Crossing: Translated by Marina Ignatjuk. N. P.

Mendes, Ana Cristina. 2018. Indie crowdfunded narratives of commercial surrogacy, or the contested bodies of Neoliberalism: Onir's I Am Afia and Arpita Kumar's Sita. In Indian cinema beyond Bollywood: The new independent cinema revolution, ed. Ashvin Devasundaram, 78-99. London: Routledge.

Mendes, Ana Cristina, and Lisa Lau. 2019. A postcolonial framing of international commercial gestational surrogacy in India: Re-orientalisms and power differentials in Meera Syal's The House of Hidden Mothers. Interventions 21 (3): 318-336.

Miglani, Bob. 2013. Embrace the chaos: How India taught me to stop overthinking and start living. San Francisco: Berrett-Koehler. Milan, Renee. 2018. Die Leihmutter. Munich: Knaur.

Mohanty, Chandra. 2003. Under Western Eyes revisited: Feminist solidarity through anticapitalist struggles. Signs 28: 499-535. Monsoon Baby. 2014. Directed by Andreas Kleinert. Written by Florian Hanig, Andreas Kleinert, and Sandra Nettelbeck. Perf. Julia Jentsch, Robert Kuchenbuch. TV film. First airing ARD, Sept. 14, 2014, Munich: Roxy Film.

Monsoon Baby. n.d.. Crew United. https://www.crew-united.com/de/Monsoon-Baby 172708.html. Last accessed 27 Nov 2019.

Monsoon Baby: Drehbuchautor Florian Hanig. 2014. (Interview). Bayerischer Rundfunk, July 16. https://www.br.de/presse/inhalt/ pressedossiers/monsoon-baby-interview-florian-hanig-100.html. Last accessed 27 Nov 2019.

Monsoon Baby: Hintergrund-Info zum Thema Leihmutterschaft. 2014. (Press Release). Bayerischer Rundfunk, July 16. https:// www.br.de/presse/inhalt/pressedossiers/monsoon-baby-hintergrund-info-leihmutter-100.html. Last accessed 27 Nov 2019

Mould, David H. 2019. Monsoon postcards: Indian Ocean journeys. Columbus: Ohio University Press.

Müller, Angela. 2019. Indien im Sucher: Fotografien und Bilder von Südasien in der deutschsprachigen Öffentlichkeit, 1920-1980. Köln: Böhlau. Neuigkeiten zu Leihmutterschaft \& Eizellspende: Anpassung des Embryonenschutzgesetzes an die Lebenswirklichkeit. 2018. OpenPetition, Feb. 26. https://www.openpetition.de/petition/blog/anpassung-des-embryonenschutzgesetzes-an-dielebenswirklichkeit. Last accessed 27 Nov 2019.

O'Flaherty, Caroline, and Niall. 2012. Baby Ava: An Irish surrogacy story. Dublin: Liberties Press. Kindle edition.

Oelsner, Wolfgang, and Gerd Lehmkuhl. 2016. Spenderkinder: Künstliche Befruchtung, Samenspende, Leihmutterschaft und die Folgen. Munderfing: Fischer \& Gann.

Pande, Amrita. 2014a. Wombs in labor: Transnational commercial surrogacy in India. New York: Columbia University Press

Pande, Amrita. 2014b. The power of narratives: Negotiating commercial surrogacy in India. In Globalization and transnational surrogacy in India: Outsourcing life, ed. Sayantani DasGupta and Shamita Das Dasgupta, 87-106. Lanham: Lexington Books.

Ravi, Malavika. 2016. A critical analysis of the Surrogacy Regulation Bill 2016. Feminism in India, August 31. https:// feminisminindia.com/2016/08/31/critical-analysis-surrogacy-regulation-bill-2016/. Last accessed 27 Nov 2019.

Ray, Saptarshi. 2018. India bans commercial surrogacy to stop "rent a womb" exploitation of vulnerable women. The Telegraph, Dec. 20. https://www.telegraph.co.uk/news/2018/12/20/india-bans-commercial-surrogacy-stop-rent-wombexploitation/. Last accessed 27 Nov 2019.

Rosenthaler, Kurt. 2004. Kalkutta - Poesie im Chaos: Leben in einer unmöglichen Stadt. Möhlin: Verlag Ismero.

Said, Edward. 1978. Orientalism. New York: Pantheon.

Saravanan, Sheela. 2018. A transnational feminist view of surrogacy biomarkets in India. Singapore: Springer.

Schuh, Daniela. 2013. Verbotene Kinder: Elternschaft, nationale Zugehörigkeit und Technologie in der Debatte über Leihmutterschaft in Frankreich und Deutschland. Riga: AV Akademikerverlag.

Sehl, Markus. 2019. BGH zu Leihmutterschaft im Ausland: Kein Mutterschafts-Import aus Ukraine. LTO: Legal Tribune Online April 23. https://www.lto.de/recht/hintergruende/h/bgh-xiizb53017-leihmutterschaft-eltern-kind-abstammung-auslandfamilie-ukraine/. Last accessed 27 Nov 2019.

Tillotama Shome. 2010. http://www.tillotamashome.com. Last accessed 27 Nov 2019.

Shriva. 2017. How does Bollywood depict surrogacy and how is it harmful? Feminism in India, May 31. https:// feminisminindia.com/2017/05/31/bollywood-depict-surrogacy-harmful/. Last accessed 27 Nov 2019.

Spiewak, Martin. 2010. Leihmutterschaft: Verbotene Kinder. Die Zeit, April 22. https://www.zeit.de/2010/17/Leihmutterschaft. Last accessed 27 Nov 2019.

Straßmann, Markus. 2012. Leihmutterschaft: Bauch zu vermieten: Elternschaft mit Leihmüttern, Ei- und Samenspendern wird kompliziert - besonders für Standesbeamte. Die Zeit, Nov. 22. https://www.zeit.de/2012/48/LeihmutterschaftGesetzgebung-Standesbeamte. Last accessed 27 Nov 2019.

Surrogacy in India. 2016. (Video recording). https://www.youtube.com/watch?v=p7kIWc7S8IQ. Last accessed 27 Nov 2019. Syal, Meera. 2015. The house of hidden mothers. A novel. London: Doubleday.

Thorn, Petra. 2008. Expertise: Reproduktives Reisen. Pro Familia: Deutsche Gesellschaft für Familienplanung, Sexualpädagogik und Sexualberatung. Frankfurt a. M.. https://www.profamilia.de/fileadmin/publikationen/Fachpublikationen/expertise reproduktives_reisen.pdf. Last accessed 27 Nov 2019

Vajracharya, Gautama V. 2013. Frog hymns and rain babies: Monsoon culture and the art of ancient South Asia. Mumbai: Marg Foundation.

Wilson, Jon E. 2016. India conquered: Britain's raj and the chaos of empire. London: Simon \& Schuster UK.

Zipes, Jack, trans. 1992. The complete fairy tales of the Brothers Grimm. New York: Bantam Books.

\section{Publisher's Note}

Springer Nature remains neutral with regard to jurisdictional claims in published maps and institutional affiliations. 